\title{
Land Value Recapture in the US: the Case of San Francisco Nico Calavita ${ }^{1, a}$ \\ ${ }^{1}$ San Diego State University, Campanile Drive, San Diego, CA (USA) \\ ancalavit@mail.sdsu.edu
}

Keywords: Land Value Recapture, Economic Analyses, Planning Culture.

\begin{abstract}
During the period immediately after World War II, planning in North America and Europe followed highly centralized, top-down, command-and-control approaches that were based on the rational-comprehensive model of planning, which implies an all-knowing, all-powerful government. Part and parcel of this approach was the government's control of development land and its value. Beginning in the 1970s, as the precepts of an all-knowing, interventionist state clashed with the reality of uncontrollable global forces driven by multinationals and international finance, it became clear that planning had become a market-driven process, a "servant of the market," and that inflexible, detailed plans would not work in most real-life situations. Consequently, such plans were either ignored or overridden. This crisis of planning spurred a search for alternatives based on public-private partnerships, negotiation, and flexibility including ways to transfer increased land values to the public trough the development process. This approach is generally known as Land Value Recapture (LVR). This paper presents an example of LVR in the US, a rather unique example in the US. It concludes by suggesting that the belief that the increase in land values is not the result of the landowner's activities, and are therefore "unearned" and should be recaptured for the public benefit, is not part of the American planning culture. LVR, then, might have a hard time supplanting other market-based regulatory strategies that are voluntary for developers and less restrictive of property rights for the landowner.
\end{abstract}

\section{Introduction}

During the period immediately after World War II, planning in North America and Europe followed highly centralized, top-down, command-and-control approaches that were based on the rational-comprehensive model of planning, which implies an all-knowing, all-powerful government. Part and parcel of this approach was the government's control of development land and its value. Beginning in the 1970s, as the precepts of an all-knowing, interventionist state clashed with the reality of uncontrollable global forces driven by multinationals and international finance, it became clear that planning had become a market-driven process, a "servant of the market," and that inflexible, detailed plans would not work in most real-life situations. Consequently, such plans were either ignored or overridden.

This crisis of planning spurred a search for alternatives based on public-private partnerships, negotiation, and flexibility including ways to transfer increased land values to the public trough the development process. This approach is generally known as Land Value Recapture (LVR). Calavita and Mallach [1], in their Inclusionary Housing in International Perspective: Affordable Housing, Social Inclusion, and Land Value Recapture, developed a table on the extent and explicitness of Land Value Recapture in the seven countries they analyzed. They came up with four different recapture models:

1. Countries with explicit and extensive recapture mechanisms (Spain and England);

2. Countries with explicit but limited recapture (Ireland);

3. Countries where recapture is implicit or ambiguous (Italy, France, and Canada); and

4. Countries where value recapture has not been part of the planning culture (United States).

But the characterization of the US situation is not entirely true. While it might be true that value recapture has not been, explicitly, part of the planning culture of the US, it is also true that over the past thirty years or so, many localities have adopted regulatory financing schemes, i.e., "exactions," most typically in the form of Development Impact Fees (DIFs). Such fees, that have to be 
proportional to the need generated by development, can be considered a form of Land Value Recapture. Economists agree that, in the long run, land markets will adjust to the added costs of Development Impact Fees.

The same is true for Inclusionary Housing and Commercial Linkage Fees. In the first case, residential developers have to provide a small percentage of their market-rate units to low-income units. In the second, developers of commercial developments pay a "linkage fee", based on the need created by their development for affordable housing.

All these exactions were adopted independently by local governments mostly in major metropolitan areas because of the increasing financial need for infrastructure, public facilities and affordable housing at a time of retrenchment of the Federal government.

The fact that land markets would adjust to reflect the added costs of development (a form of land value recapture) by reducing land costs, thus not adding to the costs of development, has not been part of the discussion. The idea that urban land values increase because of public activities and should be recaptured for the public benefit, has not been, in fact, part of the US planning culture; until now. Recently, a few cities have begun to engage in Land Value Recapture. The term that has been used for this process, especially in the San Francisco Bay Area, is "Public Benefit Zoning." Presumably, Public Benefit Zoning (PBZ) immediately and clearly captures the basic premise of this approach--that is, that benefits to the community should accrue when zoning and other land use changes that benefit the landowner are granted by public agencies. But the real reason for the use of the PBZ term, and not "recapture" is that probably there is still some wariness in engaging in a process that might be perceived as infringing on land-owners' property rights. As the following case study shows, it takes a confluence of several factors to bring about acceptance of Land Value Recapture, albeit under a different name.

\section{Land Value Recapture in San Francisco: The Case of the Eastern Neighborhoods Plan}

It could be argued that Land Value Recapture in the United States was invented in San Francisco in the early part of this century. It came about as a result of the conflicts that arose from the dot.com boom of the late twentieth century, as certain areas east of Market Street - primarily the mostly latino Mission District - experienced rapid increases in real estate values, gentrification, and displacement of families and businesses. This process was aided by city policies that exempted "live-work" spaces in warehouses and industrial structures from processing and Development Impact Fees requirements.

The story of that struggle has been told elsewhere and will not be repeated here $[2,3,4]$. In this case study we will briefly explain how LVR in San Francisco was an outcome of, and shaped by, those conflicts.

\section{Public-Benefit Incentive Zoning}

The coalition that formed to fight the changes occurring in their neighborhoods (the Mission Anti-Displacement Coalition-MAC) decided when the city initiated a planning process for those areas, that they would create their own plan, called the People's Plan for Jobs, Housing, and Community. Instead of reacting to the City's plans, the neighborhoods decided to establish first "what they wanted" and then "how to get it."

As part of the People's Plan preparation, the leaders of MAC came up with the idea of LVR. They called it "Public Benefit Incentive Zoning" (PBIZ). They argued that increases in density create "greater value for property owners and sales or rental value for developers," and that PBIZ, could create"a mechanism to capture a portion of this increased land value in the form of Public Benefits that would mitigate the impact of the additional development." In two pages, the leaders of MAC had set up the rationale for utilizing LVR to obtain public benefits through the planning process. While it is impressive that community activists could create such a sophisticated proposal for LVR, it must be remembered that the planning culture and political environment in San Francisco is imbued with the principle that growth should pay for the costs it generates. This policy 
dates back to commercial linkage fees that were established in San Francisco in the early 1980's as a result of the surge of office developments that were changing the face of downtown San Francisco. Opponents of the "Manhattanization" of San Francisco and affordable housing advocates found inspiration in the idea of "mitigation" that is an integral part of the California Environmental Quality Act, i.e. that the adverse environmental impact associated with development should be anticipated and mitigated. In this case, office development job growth resulted in an increased need for affordable housing. The mitigation to this impact were the office linkage fees established in San Francisco in 1985, requiring large office developments to contribute to an affordable housing trust fund that would help finance affordable housing. San Francisco was the first city in the country to adopt these fees.

In 2001, this program was re-named the Jobs-Housing Linkage Program (JHLP) and was revised to require all commercial projects with a net addition of 25,000 gross square feet or more to contribute to the fund. The linkage fees were extended to other commercial uses in 2001. In addition to the linkage fee for jobs and housing, San Francisco currently imposes development impact fees for transit and parks, in-lieu fees for child care facilities and inclusionary housing, and a capacity charge for wastewater treatment.

The idea of PBZ was at first rejected by the City as anti-development in 2004. In the meantime, the planning department had begun a planning process for an area that included not only the Mission, but also Potrero Hills/Showplace Square, the eastern portion of South of Market and Central Waterfront - the so-called "Eastern Neighborhoods" (ENs). With the planners in charge of the planning process sympathetic to the goals of the MAC, the principle of LVR was eventually embraced by the City. The question remained as to how this recapture would work. The following sections present the process.

\section{How the LVR program in San Francisco was developed}

\section{Needs Assessment}

The first step consisted of assessing the existing and future needs in the ENs. This process would lead to the establishment of a "package" of public benefits. A needs analysis was performed consisting of two approaches. The first was an assessment of current and future needs for some key services and amenities prepared by a consultant and based on a land-use scenario prepared by the Planning Department in 2003. A draft of the findings was published in September 2006, and the final consultant report was completed in December of 2007. It was based, in part, on a socioeconomic impact analysis prepared by another consultant and released in March 2007.

This standard-based/quantitative analysis produced a list of services/amenities that would be needed in the future that included, among others, recreational facilities, public health and human services centers, transportation and transit services and affordable housing. It also included projections for maintenance and operating expenses for parks and recreational facilities. The need for affordable housing was based on ABAG estimates that 64 percent of new housing production in San Francisco needed to be affordable. Within the Eastern Neighborhoods, this translated to 1,901 units affordable to very low-income households, 771 to low-income households and 2,044 to moderate-income households, for a total of 4,716 affordable units, over half of the 7,385 anticipated units.

The second approach was based on a series of meetings with the community. This so-called "Qualitative Analysis" incorporated the community feedback from numerous workshops that took place from September 2006 to March 2007 in various areas of the ENs. As a result of these needs assessments, two major areas of concern were identified. First was the need for affordable housing in neighborhoods that traditionally had housed people working in the service and manufacturing industries in the ENs. Second was the need to fill the gap in the existing infrastructure and public facilities, and meet the needs generated by new development. The cost of the public benefits was calculated to be approximately $\$ 300$ million [5]. 


\section{The Plan}

The existing land uses in the Eastern Neighborhoods included for the most part underutilized industrial areas that became very appealing to speculators during the dot.com boom. Because of inadequate land use controls at the time, these developers could turn industrial buildings into "livework" units, (but actually live-only spaces in the great majority of cases), with a simple conditional use permit, without paying development impact fees. This was potentially very profitable for developers who bought the land at lower, industrial prices, and eventually for landowners because it effectively converted industrial land into more valuable residential land that could command higher prices. The plan's main task was to identify the areas that could be changed from these "grey" areas (industrial but easily changeable to residential) to mixed use/residential, and those areas where industrial uses, mainly Production, Distribution and Repair uses (PDR) would remain. Much of the discussion was centered on the determination of how much of San Francisco's remaining industrial lands should be transitioned to other uses, especially needed residential uses. PDR uses were maintained in the more traditional industrial zones. Also, while allowing density increases in all the ENs, the Plan allowed significant higher densities/height only in areas to the North of the ENs, close to Rincon Hill and the CBD.

\section{Baseline and Bonus/Upzoning Fees}

In addition to increases in density in all Eastern Neighborhoods, the Plan provided additional benefits to land owners and developers, including height increases, removal of conditional use permits for residential uses in all areas - except for PDR preservation districts - and changes in land-use designations from industrial in some areas to residential uses. The Eastern Neighborhoods Plan offered the ability to reduce the need for additional environmental studies by tiering off the EN Plan EIR.

These changes would generally increase the value of land covered by these provisions, since less expensive industrial land is converted to more valuable residential land, which presently is in high demand in San Francisco. In order to learn more about how much these changes enhanced land values, the City hired a consultant to prepare a residual land value analysis to estimate the enhanced value from these upzonings and land use changes. (An example of this residual land value analysis is presented at the end of this section.) It was based on a representative subset of nine prototypes combining different densities/heights and lot sizes. The analysis showed that "residual land values and profitability are generally higher under proposed zonings and requirements than under current zoning," even though "value increases are offset to some extent by higher development costs associated with taller, denser development types" [6] .

The question remained as to how, and how much of, this value could be recaptured for public benefits.

The City had two choices: 1) to recapture land values through individual project "deals," utilizing development agreements or similar instruments or 2) to establish a priori the level of public benefit to be expected, proportional to the benefit received, exercised through a system of fees. The City chose the second option - what we have labeled the "plan-based" approach. With this approach, the City "aimed to state clearly up front what benefit contributions will be, based on a proxy of benefit gained.

The development community gains certainty about what will be required to contribute, and the neighborhood gains certainty about what improvements can be expected" [7]. The plan-based approach was especially attractive in a city like San Francisco, where the development process is perceived to be extremely politicized with deals conducted behind closed doors.

- The bonus/upzoning fee was only one source of funding for the package of community benefits that had been identified through the needs analyses. Additional revenue sources identified to pay for benefits included Baseline Impact Fees, Assessment Districts, Regional and State Funding, General Fund, Tax Increment and Grants \& Bonds. 
Baseline impact fees are the fees that can legally be imposed on new development for the needs it creates for capital facilities such as libraries, transportation, recreation and parks and child care facilities. In addition, new development is subject to citywide exactions such as the Citywide Transit Impact Development Fees and the School Impact Fee. In May 2008 a consultant report was released that provided information on the maximum amount that could be charged. Similarly, a citywide housing nexus study prepared in 2006 established the maximum amount that could be required for affordable housing.

\section{The Solution: A Tiered Program of Combined Fees and Housing Options}

\section{Tiered Approach}

To reflect the relationship between higher densities and increased value for land and development, the City established a "Tier" approach to baseline fees and public benefit fees. (See Table A-1.)

Table A-1. FEE SCHEDULE FOR EASTERN NEIGHBORHOODS PLAN AREAS ${ }^{(1)}$

\begin{tabular}{|c|l|c|c|}
\hline Tier & Description & Residential & Commercial \\
\hline 1 & $\begin{array}{l}\text { Projects that remain at current height. } \\
\text { Projects under increased housing requirements (UMU), Affordable } \\
\text { housing or other "protected" development types. }\end{array}$ & $\$ 8 / \mathrm{gsf}$ & $\$ 16 / \mathrm{gsf}$ \\
\hline 2 & $\begin{array}{l}\text { Projects rezoned with minimal (1-2 story) increase in height. } \\
\text { Projects rezoned with significant (3 or more) increase in height; other } \\
\text { designated districts. }\end{array}$ & $\$ 12 / \mathrm{gsf}$ & $\$ 20 / \mathrm{gsf}$ \\
\hline
\end{tabular}

(1) It should be noted that all fees are based on net addition of gross square feet (gsf) of any use type.

Source: City of San Francisco: Materials for Eastern Neighborhoods Area Plans Initiation Hearings, April 17, 2008.

Baseline impact fees are paid by projects that remain at current height (Tier 1), because there is no increment in value resulting directly from governmental action, although values may have increased as housing demand and prices have spiked.

In existing mixed-use areas, a second and third tier of impact fees are triggered where the Plan grants additional heights - specifically, Tier 2 applies to an increase of one to two stories, and Tier 3 applies when three or more stories are permitted. The fees for Tiers 2 and 3 constitute baseline fees plus additional public benefit zoning fees. The baseline impact fees were set at $85 \%$ to $95 \%$ of the full costs attributable to new development, to make sure that the fees did not exceed reasonable costs, and to make them "generally feasible under current market conditions." In reference to the public benefit zoning fees, the EN Implementation document reiterated that the rezonings which allow greater height increase "see a significant increase in land value ... resulting in a more profitable project, which is therefore able to pay closer to its full of impact" [8].

\section{Increased Inclusionary Housing Requirements}

To fulfill the goal of increased affordable housing production in the ENs, the Plan also requires that in areas rezoned from industrial to mixed (mostly residential) uses, more affordable housing be produced than is required under the City's inclusionary program. Within these zones, the Plan provides greater flexibility in the way affordable housing requirements can be met so that higher percentages of affordability are actually achievable (see Table A-2). Thus, properties that are rezoned from industrial to mixed land uses are responsible to meet inclusionary housing requirements as well as pay fees under the City's Program. 
Table A-2. HOUSING REQUIREMENTS FOR THE UMU DISTRICT 12

\begin{tabular}{|c|l|c|c|c|c|}
\hline Tier & Description & $\begin{array}{l}\text { On-Site } \\
\text { Housing } \\
\text { Requirement }\end{array}$ & $\begin{array}{l}\text { Off-Site/In-Lieu } \\
\text { Requirement }\end{array}$ & $\begin{array}{l}\text { Middle } \\
\text { Income } \\
\text { Alternative }\end{array}$ & $\begin{array}{l}\text { Land } \\
\text { Dedication } \\
\text { Alternative }\end{array}$ \\
\hline A & $\begin{array}{l}\text { Projects that remain at current } \\
\text { height. }\end{array}$ & $18 \%$ & $23 \%$ & $40 \%$ & $35 \%$ \\
\hline B & $\begin{array}{l}\text { Projects in the UMU rezoned with } \\
\text { minimal (1-2 story) increase in } \\
\text { height. }\end{array}$ & $20 \%$ & $25 \%$ & $50 \%$ & $40 \%$ \\
\hline C & $\begin{array}{l}\text { Projects in the UMU rezoned with } \\
\text { significant (3 or more) increase in } \\
\text { height; other designated districts. }\end{array}$ & $22 \%$ & $27 \%$ & $60 \%$ & $50 \%$ \\
\hline
\end{tabular}

Source: City of San Francisco: Materials for Eastern Neighborhoods Area Plans Initiation Hearings, April 17, 2008

\section{Implementation}

The base public benefit fee of $\$ 8$ for residential gsf (gross square foot) and $\$ 16$ for commercial gsf are dedicated to fund capital infrastructure (open space and recreational facilities, transit, streetscape and public realm improvements). Fees above that base level are also geared toward infrastructure funding, but a small percentage of those funds can also be dedicated to community facilities, such as child care and library materials.

To help implement the plan the Eastern Neighborhoods Citizen's Advisory Committee (EN CAC) was established by the city. As a city site explains: "The EN CAC is the community advisory body charged with providing input to City agencies and decision makers with regard to all activities related to implementation of the Eastern Neighborhoods Area Plans. The CAC is established for the purposes of providing input on the prioritization of Public Benefits, updating the Public Benefits program, relaying information to community members in each of the four neighborhoods regarding the status of development proposals in the Eastern Neighborhoods, and providing input to plan area monitoring efforts as appropriate." Their recommendations are coordinated with the Interagency Planning and Implementation Committee and the Capital Program Committee.

Given the real estate decline that begun at the time of the approval of the EN Plan, the amount of fees collected has been rather small, generating frustration among CAC members. Additionally, encourage development, the city established a fee deferral process. But now (2014) the market is hot again, and fees are starting to pour in. Yet, one has to wonder weather this plan-based approach, with its emphasis on certainty and legal care, has missed the boat in terms of recapturing a significant portion of increases in land values. In fact, with the skyrocketing increases in real estate values at this time, it is probable that fee levels are too low to significantly lower land values.

Example of a Residual Land Value Analysis

Table A-3 provides the residual land value analysis that can be used to estimate the value enhancement from revised zoning. Residual land value analyses calculate the costs of development, including the profit of the developer, and the gains from the selling or renting of the development. What is left is the value of the land. In areas where the market is weak or nonexistent - as in areas in need of regeneration for example - the land value will be negative, and government subsidies would be necessary in order for redevelopment to occur. The following table shows that, with increased density, the value of the land increases. 
Table A-3. Residual Land Value

Tier 1, Existing Residential/Commercial Zones, Onsite IH

San Francisco Eastern Neighborhoods [9]

\begin{tabular}{|c|c|c|c|}
\hline & $\begin{array}{l}\text { Current Zoning } \\
N C\end{array}$ & $\begin{array}{l}\text { Proposed Zoning } \\
N C T\end{array}$ & Difference \\
\hline $\begin{array}{l}\text { Site Area and Zoning } \\
\text { Lot Size } \\
\text { Lot Acreage } \\
\text { Ground Floor Lot Coverage }^{\mathrm{a}} \\
\text { Maximum Residential Lot Coverage (Above Ground Floor) } \\
\text { Maximum Residential Density }\end{array}$ & $\begin{array}{l}20,000 \text { Square Feet } \\
0.46 \quad \text { Acres } \\
100 \% \\
75 \% \\
600 \text { Lot } \\
\end{array}$ & $\begin{array}{rr}20,000 & \text { Square Feet } \\
0.46 \quad \text { Acres } \\
100 \% & \\
75 \% & \\
\text { N/A } & \end{array}$ & \\
\hline $\begin{array}{l}\text { Development Program } \\
\text { Description } \\
\text { Maximum Height } \\
\text { Maximum Total Floors } \\
\text { Building Efficiency } \\
\text { Residential } \\
\text { Average Unit Size } \\
\text { Units per Floor } \\
\text { Maximum } \text { Units }^{\mathrm{d}} \\
\text { Unit Mix } \\
\\
\text { Number of Market Rate Units } \\
\text { Number of BMR Units } \\
\text { Parking } \\
\text { Average Parking Ratio }\end{array}$ & $\begin{array}{l}\begin{array}{l}\text { Low Rise Podium } \\
50 \text { Feet }\end{array} \\
5 \text { Floors } \\
\quad 80 \% \\
\text { 1,200 Square Feet } \\
10 \text { Units } \\
33 \text { Units } \\
0 \% 1 \text { BR } \\
80 \% 2 \text { BR } \\
20 \% 3 \text { BR } \\
28 \text { Units } \\
5 \text { Units } \\
\quad 1 \text { Space per Unit }\end{array}$ & 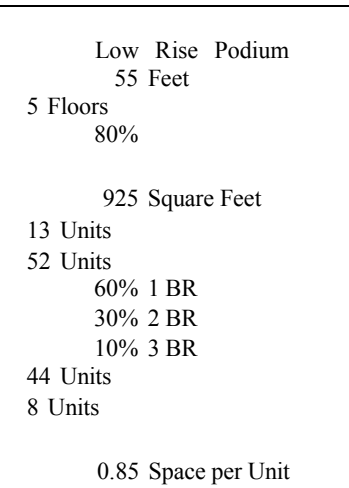 & $\begin{array}{r}16 \text { Units } \\
3 \text { Units }\end{array}$ \\
\hline $\begin{array}{l}\text { Revenue } \\
\text { Market Rate Sales Price }{ }^{\mathrm{g}} \\
\text { Average MR Sales Price Adjusted for Parking } \\
\text { Base Price of BMR Units } \\
\text { Sales Expense } \\
\end{array}$ & $\begin{array}{l}\text { \$717 } \text { Per Net Square Foot } \\
\$ 859,891 \text { Per MR Unit } \\
\$ 859,891 \text { Per MR Unit } \\
\$ 242,771 \text { Per BMR Unit } \\
4.0 \% \\
\end{array}$ & $\begin{array}{l}\text { \$754 Per Net Square Foot } \\
\text { \$697,718 Per MR Unit } \\
\$ 690,987 \text { Per MR Unit } \\
\$ 223,134 \text { Per BMR Unit } \\
4.0 \%\end{array}$ & \\
\hline Sales Net of Sales Expense & $\begin{array}{r}\$ 24,413,318 \\
\$ 739,798 \text { Per Unit } \\
\$ 616 \text { Per NSF }\end{array}$ & $\begin{array}{r}\$ 31,086,739 \\
\$ 597,822 \text { Per Unit } \\
\$ 646 \text { Per NSF }\end{array}$ & $\$ 6,673,421$ \\
\hline $\begin{array}{l}\text { Building Costs }^{g} \\
\text { Hard Construction (incl. parking) } \\
\text { Governmental Fees } \\
\text { Permits and Processing Charges } \\
\text { Additional 2007 Water and Sewer Impact Fees } \\
\text { Inclusionary Housing In-Lieu Fee } \\
\text { School Impact Fee } \\
\text { Eastern Neighborhoods Impact Fee } \\
\text { Other Soft Costs } \\
\text { Construction Financing }\end{array}$ & $\begin{array}{l}\text { \$276 Per NSF } \\
\$ 8 \text { Per NSF } \\
\$ 6,000 \text { Per Unit } \\
\text { \$508 Per Unit } \\
\text { \$0 Per Unit } \\
\text { \$2.24 Per NSF } \\
\text { \$0 Per NSF } \\
\text { \$100 Per NSF } \\
\text { \$28 Per NSF } \\
\end{array}$ & $\begin{array}{l}\text { \$289 Per NSF } \\
\$ 19 \text { Per } N S F \\
\text { \$6,000 Per Unit } \\
\text { \$508 Per Unit } \\
\text { \$0 Per Unit } \\
\quad \text { \$2.24 Per NSF } \\
\text { \$10.00 Per NSF } \\
\text { \$100 Per NSF } \\
\text { \$28 Per NSF }\end{array}$ & $\$ 10$ \\
\hline Total Building Costs & $\begin{array}{r}16,295,730 \\
\$ 493,810 \text { Per Unit } \\
\$ 412 \text { Per NSF } \\
\end{array}$ & $\begin{array}{r}\$ 20,941,517 \\
\$ 402,721 \text { Per Unit } \\
\$ 435 \text { Per NSF } \\
\end{array}$ & $\$ 4,645,787$ \\
\hline $\begin{array}{l}\text { Residual Land Value } \\
\text { Return on Net Sales } \\
\text { Developer Margin }\end{array}$ & $\begin{array}{c}15.4 \% \\
\$ 3,759,651 \\
\$ 113,929 \text { Per Unit } \\
\end{array}$ & $\begin{array}{c}15.4 \% \\
\$ 4,787,358 \\
\$ 92,065 \text { Per Unit } \\
\end{array}$ & $\$ 1,027,707$ \\
\hline $\begin{array}{l}\text { Land Value } \\
\text { Per Unit } \\
\text { Per Net Residential Square Foot } \\
\text { Per Gross Residential Square Foot } \\
\text { Per Lot Square Foot } \\
\text { Per Acre of Land } \\
\text { Representative Site Land Value }\end{array}$ & $\begin{array}{l}\$ 132,059 \text { Per Unit } \\
\$ 110 \text { Per NRSF } \\
\$ 88 \text { Per GRSF } \\
\$ 218 \text { Per LSF } \\
\$ 9,491,587 \text { Per Acre } \\
\$ 4,357,937\end{array}$ & $\begin{array}{l}\$ 103,036 \text { Per Unit } \\
\$ 111 \text { Per NRSF } \\
\$ 89 \text { Per GRSF } \\
\$ 268 \text { Per LSF } \\
\$ 11,669,429 \text { Per Acre } \\
\$ 5,357,865\end{array}$ & $\begin{array}{r}-\$ 29,023 \text { Per Unit } \\
\$ 1 \text { Per NRSF } \\
\$ 1 \text { Per GRSF } \\
\text { \$5 Per LSF } \\
\$ 2,177,842 \text { Per Acre } \\
\$ 999,928\end{array}$ \\
\hline Site value increase as a percent of current zoning $b$ & & & $22.9 \%$ \\
\hline
\end{tabular}

Source: Eastern Neighborhoods Impact Fee and Affordable Housing Analysis, Prepared by Seifel Consulting for the City of San Francisco (May 22, 2008)

\section{Conclusions}

It took a period of intense urban conflict, sophisticated activism and a sympathetic administration to bring about a Land Value Recapture scheme for the City of San Francisco. A few other cities, such as Santa Monica in California for example, are engaging in land value recapture. It 
is not clear at this point if this approach will take hold, or municipalities will continue to engage in other "market-based" regulatory strategies" [10] particularly incentive zoning. Incentive Zoning, or Density Bonus, is an approach that closely resembles LVR, but with some important differences. Under incentive zoning, when a developer buys a piece of land that has been up-zoned, he/she pays the increased value of the land. Under LVR, some of that increase is captured for community benefits to be paid for by the developer, and so the developer is bound to pay less for the land.

With incentive zoning it is the developer who, for additional density, voluntarily provides additional benefits. It should not affect the value of the land if the incentive is no more and no less than what is necessary to have the development work out financially. With LVR, the public, and potentially the developer, get more, but in a country with a strong support for property rights, that might not be enough to move in the direction of LVR in a significant way. Until now, the belief that the increase in land values is not the result of the landowner's activities, and are therefore "unearned" and should be recaptured for the public benefit, is not part of the American planning culture. LVR, then, might have a hard time supplanting other market-based regulatory strategies that are voluntary for developers and less restrictive of property rights for the landowner.

\section{References}

[1] Calavita, Nico \& Alan Mallach: Inclusionary Housing in International Perspective: Affordable Housing, Social Inclusion, and Land Value Recapture; Lincoln Institute of Land Policy, Cambridge, Massachussetts (2010)

[2] P. Cohen, M. Fernando: Searching for the sweet spot in San Francisco. In: Libby Porter \& Kathy Show, (2009), Whose Urban Renaissance? An International Comparison of Urban Regeneration Strategies, Routledge: London (2009)

[3] A. Fishman: Community Development Corporations' Strategies Against Gentrification and Displacement: Leading Community Movements in Park Slope, Brooklyn and in the Mission District of San Francisco, Master's Thesis, New York University Robert F. Wagner Graduate School of Public Service (2006)

[4] Marti, Fernando et.al.: Planning Against Displacement: A decade of progressive communitybased planning in San Francisco's Mission District. In: Diagolos: Placemaking in Latino Communities, Michael Rios \& Leonardo Vasquez, eds.; Routledge: London (2012)

[5] S. Dennis: Public Benefit Zoning and Community Involvement in San Francisco: The Case of the Eastern Neighborhood Plan. Paper presented at the Urban Affairs Conference, San Francisco, April (2013)

[6] Seifel Consulting Inc.: San Francisco Eastern Neighborhoods Nexus Study, prepared for the San Francisco Planning Department; May (2008)

[7] S. Dennis: Eastern Neighborhoods DRAFT Financial Analysis, Memorandum to interested parties. In: San Francisco Planning Department, Feb 27 (2008)

[8] City of San Francisco Planning Department, Planning Commission Documents June 2008 (An Executive Summary from Planning Department Staff, The Eastern Neighborhoods Financial Analysis, developed by Seifel Consulting Inc. Accessed on June 26, 2013. Information on: http://www.sf-planning.org/Modules/ShowDocument.aspx?documentid=1335

[9] Seifel Consulting Inc.: Eastern Neighborhood Impact Fee and Affordable Housing Analysis, Memorandum to Sarah Dennis, Planning Department, May (2008b)

[10] J. S. Kayden: Market-based Regulatory Approaches: A Comparative Discussion of Environmental and Land Use Techniques in the United States, 19 B.C. Envtl. Aff. Rev. 565, (1992). Information on: http://lawdigitalcommons.bc.edu/earl/vol19/iss3/11 